\title{
Time- and Dose-Dependent Responses of Brain Histamine to Intracerebroventricular and Intraperitoneal Administrations of Growth Hormone-Releasing Factor $\left(\mathrm{GRF}_{1-44}\right)$
}

\author{
Ramon Cacabelos, Atsushi Yamatodani, ${ }^{*}$ Hiroyuki \\ Fukui, ${ }^{*}$ Hisayoshi Nitgawa, Akira Miyake, $†$ Takehiko \\ Watanabe, $\ddagger$ Tsuyoshi Nishimura and Hiroshi Wada* \\ Department of Neuropsychiatry, Osaka University Medical \\ School, Osaka 553, *Department of Pharmacology II, \\ Osaka University Medical School, Osaka 530, $\dagger$ Department \\ of Gynecology, Osaka University Medical School, Osaka \\ 553 , and $\ddagger$ Department of Pharmacology I, Tohoku \\ University School of Medicine, Sendai 980
}

\begin{abstract}
Cacabelos, R., Yamatodani, A., Fukui, H., Nitgawa, H., Miyake, A., Watanabe, T., Nishimura, T. and Wada, H. Time- and Dose-Dependent Responses of Brain Histamine to Intracerebroventricular and Intraperitoneal Administrations of Growth Hormone-Releasing Factor $\left(G R F_{1-44}\right)$. Tohoku J. exp. Med., 1987, 151 (4), 429-442 — Changes in the level of histamine (HA) in rat brain induced by intracerebroventricular (i.c.v.) and intraperitoneal (i.p.) administrations of growth hormone-releasing factor $\left(\mathrm{GRF}_{1-44}\right)$ were studied. HA was determined by high-performance liquid chromatography (HPLC) in the anterior hypothalamic region, posterior hypothalamic region, median eminence, adenohypophysis, neurohypophysis, hippocampus and prefrontal cortex. $\mathrm{GRF}_{1-44}(1-10 \mu \mathrm{g}$, i.c.v.) induced significant time- and dose-dependent increases in the concentration of $\mathrm{HA}$ in the hypothalamo-hypophyseal system and time-dependent decrease of $\mathrm{HA}$ in the hippocampus. In contrast, after i.p. administration of $\mathrm{GRF}_{1-44}(10 \mu \mathrm{g})$ the level of $\mathrm{HA}$ in the hypothalamus tended to decrease but the total amount of $\mathrm{H}-1$ receptors in the hypothalamo-hypophyseal system did not change. Circadian variations in the GRF-induced HA and growth hormone responses were also observed, responses being lower in the evening than in the morning. It is concluded that GRF interacts with HA at the central level to optimize the function of the somatotropinergic system.— GRF ; brain histamine; hypothalamohypophyseal system ; GH ; H-1 receptors
\end{abstract}

Histamine (HA) is a biogenic amine that was recently shown to be a neurotransmitter (Green et al. 1978; Schwartz et al. 1980), neuromodulator (Cacabelos

Received December 23, 1986 ; accepted for publication March 5, 1987. 
1984, 1985a, b ; Cacabelos et al. 1985b, 1987) or neuroregulator (Prell and Green 1986). HA cell bodies are located in the posterior region of the hypothalamus (Panula et al. 1984 ; Steinbusch and Mulder 1984 ; Watanabe et al. 1984 ; Senba et al. 1985) sending axons in apparently organized ascending and descending pathways to the cortex (Takeda et al. 1984) and spinal cord (Wahlestedt et al. 1985). Our previous neurochemical studies suggested that there are three main intrahypothalamic HA pathways from the posterior hypothalamus to the anterior hypothalamus, median eminence and neurohypophysis (Cacabelos 1984, 1985b; Cacabelos et al. 1985b), where abundant HA fibers are detected by immunohistochemical methods using antibodies against HA (Steinbusch and Mulder 1984) and histidine decarboxylase (Watanabe et al. 1984 ; Senba et al. 1985 ; Inagaki et al., unpublished data). These intrahypothalamic HA pathways are supposed to regulate neuroendocrine functions (Cacabelos 1984, 1985a, b) and particularly corticotropinergic (Cacabelos et al. 1983, 1985b; Cacabelos 1984, 1985b) and vasopressinergic (Cacabelos 1984, 1985b ; Cacabelos et al. 1987) systems. However, HA can also influence other neuroendocrine axes, as described in several reviews (Weiner and Ganong 1978; Roberts and Calcutt 1983; Cacabelos 1984, 1985a, b ; Donoso and Alvarez 1984 ; Tuomisto and Mannisto 1985). In their transit to the infundibular region, HA fibers may establish synaptic contacts with cells secreting growth hormone-releasing factor (GRF) located in the vicinity of the nucleus arcuatus (Bloch et al. 1983; Merchenthaler et al. 1984 ; Meister et al. 1985) influencing the regulation of the somatotropinergic system. In this regard, we have recently reported that $\mathrm{GRF}_{1-29}$ can induce time- and dose-dependent changes in the level of $\mathrm{HA}$ in the hypothalamo-hypophyseal system (HhS) (Cacabelos et al. 1986a, b, c). At the same time, the i.p. administration of HA can influence the release of growth hormone (GH) (Cacabelos et al. 1986c ; Tanaka et al. 1986), enhancing the GRF-induced GH response in rats (Tanaka et al. 1986). Since structure-activity studies revealed that $\mathrm{GRF}_{1-29}$ and $\mathrm{GRF}_{1-44}$ have different effects in terms of biological potency (Wehrenberg and Ling 1983; Ling et al. 1984), in this work we studied the effects of intracerebroventricular (i.c.v.) and intraperitoneal (i.p.) administrations of $\mathrm{GRF}_{1-44}$ on brain $\mathrm{HA}$ and $\mathrm{H}-1$ receptors. We also examined circadian variations of the responses of $\mathrm{HA}$ and $\mathrm{GH}$ to $\mathrm{GRF}_{1-44}$.

\section{Materials and Methods}

\section{Experiment 1}

Male Wistar rats (Nihon Dobutsu, Osaka) weighing 150-200 g were used. The animals were housed in an air-conditioned room at $20^{\circ} \pm 0.5^{\circ} \mathrm{C}$ and $50-65 \%$ humidity with 12 -hour lighting from 7 a.m. to 7 p.m. Commercial rat chow and tap water were available ad libitum.

The animals were anesthesized with Nembutal $(40 \mathrm{mg} / \mathrm{kg}$, i.p.) and a stainless steel cannulae (G-30) was implanted into their lateral ventricle (Coordinates : $0.6 \mathrm{~mm}$ posterior to the bregma; $1.85 \mathrm{~mm}$ lateral to the medial suture; and $3.00 \mathrm{~mm}$ ventral to the dorsal surface of the skull). After a 7-day recovery period, the animals were given $\operatorname{GRF}_{1-44}(10$ $\mu \mathrm{g}$ in $5 \mu \mathrm{l} 0.9 \%$ saline, i.c.v.) between 10 and 11 a.m. and sacrificed by decapitation 5,15 
or $30 \mathrm{~min}$ later $(n=5-7 \mathrm{rats} /$ group). Control animals received the same amount of vehicle (5 $\mu 10.9 \%$ saline, i.c.v.).

The brains were removed and the anterior hypothalamic region (AHR), posterior hypothalamic region (PHR), median eminence (ME), adenohypophysis ( $\mathrm{Ah}$ ), and neurohypophysis $(\mathrm{Nh})$ of the hypothalamo-hypophyseal system $(\mathrm{HhS})$ were separated under a stereomicroscope (Konan Camera, R \& I, K-380). The hippocampus (hip) and prefrontal cortex $(\mathrm{PFCx})$ were also separated. Samples were weighed, homogenized by sonication $(7$ oc/80 Watts/15 sec; Sonifier B-12, Branson, Danbury, CT, USA) in $10 \mathrm{v} / \mathrm{w}$ of ice-cold $3 \%$ perchloric acid containing $5 \mathrm{mM}$ EDTA-Na $\mathrm{Na}_{2}$ and centrifuged at $10,000 \times \mathrm{g}$ for $15 \mathrm{~min}$ at $4^{\circ} \mathrm{C}$. The supernatants were stored at $-80^{\circ} \mathrm{C}$ for analysis.

HA was measured by high-performance liquid chromatography (HPLC) with a cation exchanger and an automated fluorometric detection system (Yamatodani et al. 1983, 1985b). Samples of 10-50 $\mu$ l were injected directly into the HPLC column. The minimum detection limit by this method was $0.05 \mathrm{pmol}$ and the inter-assay coefficient of variation was about $5 \%$.

\section{Experiment 2}

Similar rats to those for Experiment 1 were treated i.c.v. with 1,5 or $10 \mu \mathrm{g}$ of $\mathrm{GRF}_{1-44}$ ( $n=5-7$ rats/group) and the concentrations of HA in the same brain regions as for Experiment 1 were determined.

\section{Experiment 3}

Rats received an i.p. injection of $\mathrm{GRF}_{1-44}(10 \mu \mathrm{g})$ and $\mathrm{HA}$ in the HhS was determined 5,15 and $30 \mathrm{~min}$ later as described above.

\section{Experiment 4}

Rats were i.p. given 1,5 or $10 \mu \mathrm{g}$ of $\mathrm{GRF}_{1-44}(n=5-7 \mathrm{rats} /$ group $)$, and the dosedependence of changes in $\mathrm{HA}$ in the $\mathrm{HhS}$ at 15 min was examined.

\section{Experiment 5}

The animals were treated daily with $\mathrm{GRF}_{1-44}(10 \mu \mathrm{g}$, i.p. ) for 7 days and histamine H-1 receptors in the HhS were measured $30 \mathrm{~min}$ after the last treatment. HA H1-receptor binding was assayed by a modification of the method of Chang et al. (1978) and Tran et al. (1978) as described previously (Cacabelos 1985b; Cacabelos et al. 1985b).

\section{Experiment 6}

One group of rats was treated with $10 \mu \mathrm{g}$ of $\mathrm{GRF}_{1-44}$ (i.c.v. or i.p.) at $10: 00$ a.m. and a second group of rats was treated with the same amount of $\mathrm{GRF}_{1-44}$ at $8: 00$ p.m. The rats were sacrificed $0,5,10,15$, and $30 \mathrm{~min}$ later $(n=5-6$ rats/subgroup). Blood was collected from the trunk in chilled, heparinized plastic tubes and treated with $50 \mu \mathrm{l} / \mathrm{ml}$ of $o$ phenanthroline solution as described elsewhere (Cacabelos 1985b; Cacabelos et al. 1985a). GH plasma levels were determined by radioimmunoassay using kits for rat GH from the National Institute of Arthritis, Metabolism and Digestive Diseases. The sensitivity of the assay was $0.3-0.7 \mathrm{ng} \mathrm{GH} /$ tube and the intra-assay and inter-assay coefficients of variation were $9.45 \%$ and $12.5 \%$, respectively. The posterior and anterior hypothalamic regions were isolated and their HA levels were measured as in Experiments 1, 2, 3, and 4.

\section{Statistics}

Experimental data were analyzed statistically by the Student's $t$-test, analysis of variance (ANOVA) and the Mann-Whitney test using an NEC PC-9801VM2 computer. 


\section{RESULTS}

Effects of i.c.v. GRF $_{1-44}$ on the concentration of histamine in the hypothalamohypophyseal system, hippocampus and prefrontal cortex

$\mathrm{GRF}_{1-44}$ induced time-dependent changes in the concentration of $\mathrm{HA}$ in the AHR and PHR with maxima at 15 min (Fig. 1). In the ME (Fig. 1), Ah and Nh (Fig. 2) maxima were also observed at $15 \mathrm{~min}$. In the hip, $\mathrm{GRF}_{1-44}$ produced a significant decrease in the level of $\mathrm{HA}$ with a minimum at $15 \mathrm{~min}(1.35 \pm 0.23$ vs. $0.42 \pm 0.01 \mathrm{nmole} / \mathrm{g} ; t=9.03, p<0.01)$, while in the $\mathrm{PFCx}, \mathrm{HA}$ increased at $5 \mathrm{~min}$

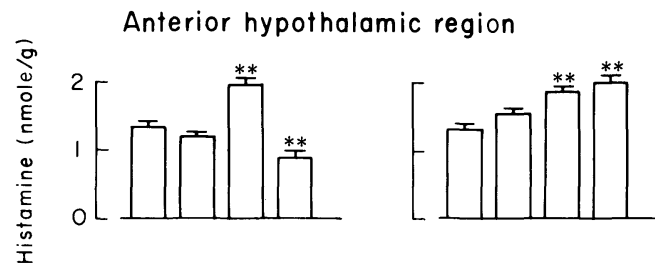

Posterior hypothalamic region
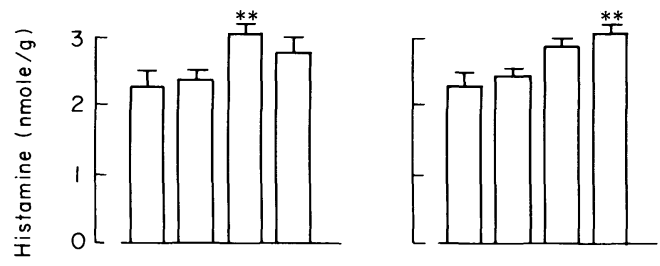

Median eminence
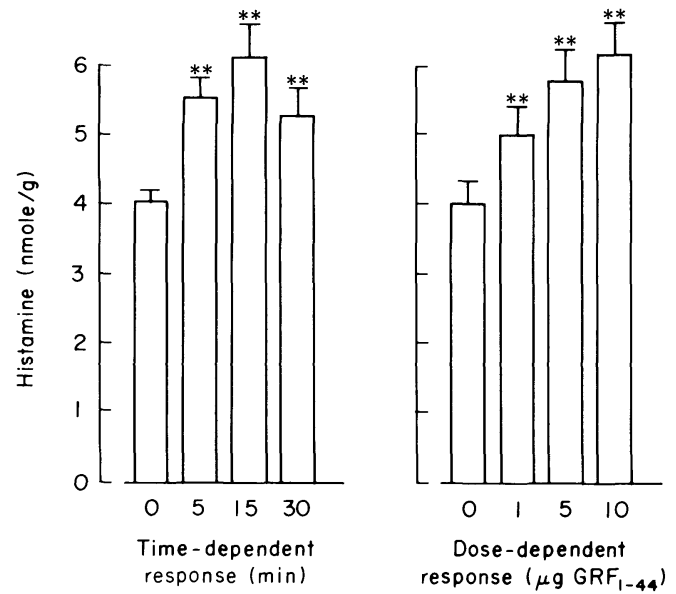

Fig. 1. GRF-induced histamine response in the anterior hypothalamic region, posterior hypothalamic region and median eminence.

$\mathrm{GRF}_{1-44}(10 \mu \mathrm{g})$ was administered i.c.v. and rats were sacrificed 5, 15 and 30 min later ( $n=5-7$ rats/group). For measurement of the dose-dependence of the response of $\mathrm{HA}$ animals were sacrificed $15 \mathrm{~min}$ after $\mathrm{GRF}_{1-44}$ injection. ${ }^{* *} p<0.01$ vs. control $(0)$. 
Adenohypophysis
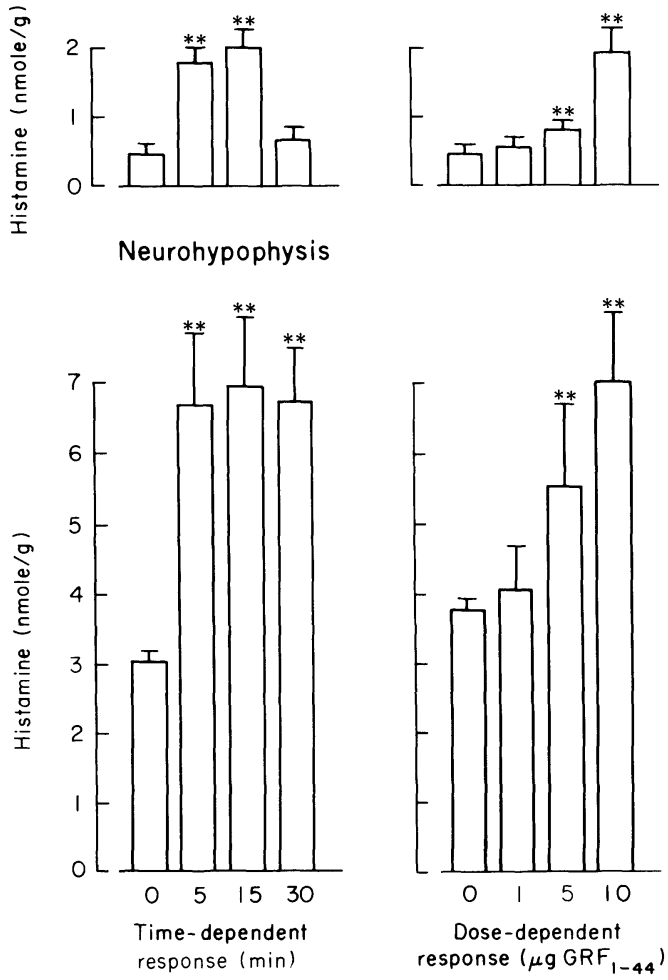

Fig. 2. GRF-induced histamine response in the adenohypophysis and neurohypophysis.

Animals were treated as for Fig. 1 (see also Materials and Methods). $\quad n=5-7$ rats/group; ${ }^{* *} p<0.01$ vs. control $(0)$.

$(0.51 \pm 0.01 \mathrm{nmole} / \mathrm{g} ; t=28.46 ; p<0.01)$ and decreased later to below the control value $(0.33 \pm 0.05 \mathrm{nmole} / \mathrm{g})$. These changes were dose-dependent. $\mathrm{GRF}_{1-44}$ elicited maximum responses at a dose of $10 \mu \mathrm{g}$ in the HhS (Figs. 1 and 2). The $\mathrm{ED}_{50}$ values were approximately $5 \times 10^{-5} \mathrm{M}$ in the hypothalamus and $\mathrm{Ah}, 2 \times 10^{-5}$ $\mathrm{M}$ in the $\mathrm{ME}$, and $4 \times 10^{-5} \mathrm{M}$ in the $\mathrm{Nh}$.

Effects of i.p. $G R F_{1-44}$ on the concentration of histamine in the hypothalamohypophyseal system

The i.p. administration of $\mathrm{GRF}_{1-44}$ induced significant decreases in the concentration of HA in the AHR and PHR at $30 \mathrm{~min}$ (Table 1). In the ME, HA increased from $5.60 \pm 0.10$ (control) to $10.34 \pm 2.25 \mathrm{nmole} / \mathrm{g}(t=4.706 ; p<0.01)$ and $14.75 \pm 3.15 \mathrm{nmole} / \mathrm{g}(t=6.80 ; p<0.01)$ after 15 and $30 \mathrm{~min}$, respectively (Table 1). In the Ah, the HA levels were decreased after 5 min and increased after 15 min (Table 1). In the Nh, the HA level was increased after 5 and $15 \mathrm{~min}$. In the hypothalamus the GRF-induced HA response was dose-dependent with 
TABLE 1. Effects of i.p. administration of $G R F_{1-44}$ on histamine contents in the hypothalamo-hypophyseal system

\begin{tabular}{lcccc}
\hline \multicolumn{1}{c}{ Region } & Control & $5 \mathrm{~min}$ & $15 \mathrm{~min}$ & $30 \mathrm{~min}$ \\
\hline $\begin{array}{l}\text { Anterior hypothalamic } \\
\text { region }\end{array}$ & $1.59 \pm 0.15$ & $1.35 \pm 0.13$ & $1.41 \pm 0.23$ & $0.98 \pm 0.05^{* *}$ \\
$\begin{array}{l}\text { Posterior hypothalamic } \\
\quad \text { region }\end{array}$ & $2.35 \pm 0.35$ & $2.20 \pm 0.16$ & $2.07 \pm 0.19$ & $1.24 \pm 0.03^{* *}$ \\
Median eminence & $5.60 \pm 0.10$ & $5.65 \pm 0.03$ & $10.34 \pm 2.25^{* *}$ & $14.75 \pm 3.15^{* *}$ \\
Adenohypophysis & $0.70 \pm 0.008$ & $0.59 \pm 0.09$ & $1.02 \pm 0.14^{* *}$ & $0.73 \pm 0.08$ \\
Neurohypophysis & $3.86 \pm 0.56$ & $5.99 \pm 0.42^{* *}$ & $8.23 \pm 1.76^{* *}$ & $4.03 \pm 0.59$ \\
\hline
\end{tabular}

Dose : $10 \mu \mathrm{g} \mathrm{GRF}_{1-44}$ (i.p.).

Histamine units: nmole/g (mean \pm s.D.).

$n=5-7$ rats $/$ group.

${ }^{* *} p<0.01$ vs. control.

TABLE 2. Dose-dependent response of brain histamine to i.p. administration of $G R F_{1-44}$

\begin{tabular}{lllcc}
\hline \multirow{2}{*}{ Region } & \multicolumn{4}{c}{ Dose $\left(\mu \mathrm{g} \mathrm{GRF}_{1-44}\right.$, i.p. $)$} \\
\cline { 2 - 5 } & \multicolumn{1}{c}{0} & \multicolumn{1}{c}{1} & \multicolumn{1}{c}{5} & 10 \\
\hline $\begin{array}{l}\text { Anterior hypothalamic } \\
\text { region }\end{array}$ & $1.59 \pm 0.15$ & $1.13 \pm 0.14^{* *}$ & $1.15 \pm 0.005^{* *}$ & $1.41 \pm 0.23$ \\
$\begin{array}{l}\text { Posterior hypothalamic } \\
\quad \text { region }\end{array}$ & $2.35 \pm 0.35$ & $1.61 \pm 0.15^{* *}$ & $1.68 \pm 0.08^{* *}$ & $2.07 \pm 0.19$ \\
Median eminence & $5.60 \pm 0.10$ & $5.15 \pm 0.96$ & $6.61 \pm 1.17$ & $10.34 \pm 2.25^{* *}$ \\
Adenohypophysis & $0.70 \pm 0.008$ & $0.55 \pm 0.04^{* *}$ & $0.69 \pm 0.09$ & $1.02 \pm 0.14^{* *}$ \\
Neurohypophysis & $3.86 \pm 0.56$ & $3.98 \pm 0.91$ & $5.18 \pm 0.88^{* *}$ & $8.23 \pm 1.76^{* *}$ \\
\hline
\end{tabular}

Time: $15 \mathrm{~min}$.

Histamine units : nmole/g (mean \pm S.D.)

$n=5-7$ rats group.

${ }^{* *} p<0.01$ vs. control $(0)$.

maximum inhibition at low doses of $\mathrm{GRF}_{1-44}$ (Table 2). Increasing doses of $\mathrm{GRF}_{1-44}$ potentiated the response of $\mathrm{HA}$ in the $\mathrm{ME}, \mathrm{Ah}$, and $\mathrm{Nh}$ (Table 2) with $\mathrm{ED}_{50}$ values of $9.9 \times 10^{-6} \mathrm{M}, 1.3 \times 10^{5} \mathrm{M}$, and $1.1 \times 10^{-5} \mathrm{M}$, respectively.

Effects of i.p. $\mathrm{GRF}_{1-44}$ on $\left[{ }^{3} \mathrm{H}\right]$-mepyramine binding in the hypothalamohypophyseal system

The administration of $\mathrm{GRF}_{1-44}$ at a daily dose of $10 \mu \mathrm{g}$ (i.p.) for 7 days did not modify the total amount of $\mathrm{HA} \mathrm{H}-1$ receptors in any region of the HhS (Table $3)$.

Circadian oscillations in the $G R F$-induced $H A$ and $G H$ responses

When administered i.c.v. in the morning, $\mathrm{GRF}_{1-44}$ induced significant 
TABLE 3. Effect of i.p. GRF $F_{1-44}$ on $\left[{ }^{3} \mathrm{H}\right]$-mepyramine binding in the hypothalamo-hypophyseal system

\begin{tabular}{lcc}
\hline \multicolumn{1}{c}{ Region } & Control & $\mathrm{GRF}_{1-44}$ \\
\hline Anterior hypothalamic region & $13.25 \pm 0.85$ & $15.25 \pm 3.35$ \\
Posterior hypothalamic region & $14.95 \pm 2.55$ & $16.10 \pm 3.20$ \\
Median eminence & $45.85 \pm 7.15$ & $49.15 \pm 4.85$ \\
Adenohypophysis & $18.40 \pm 6.80$ & $10.50 \pm 4.05$ \\
Neurohypophysis & $57.15 \pm 9.15$ & $66.10 \pm 5.90$ \\
\hline
\end{tabular}

Dose : $10 \mu \mathrm{g} \mathrm{GRF}_{1-44} /$ day for 7 days, (i.p.).

Anterior hypothalamic region

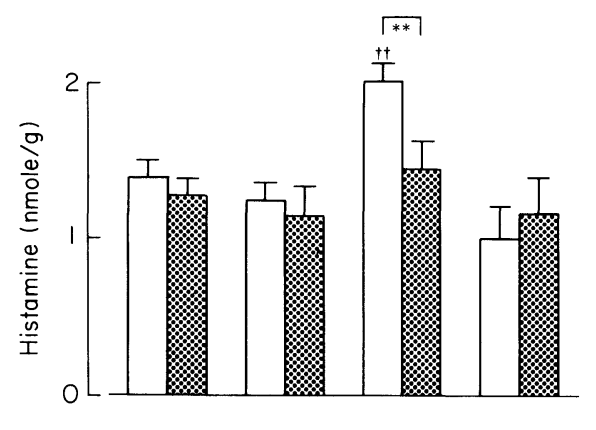

Posterior hypothalamic region

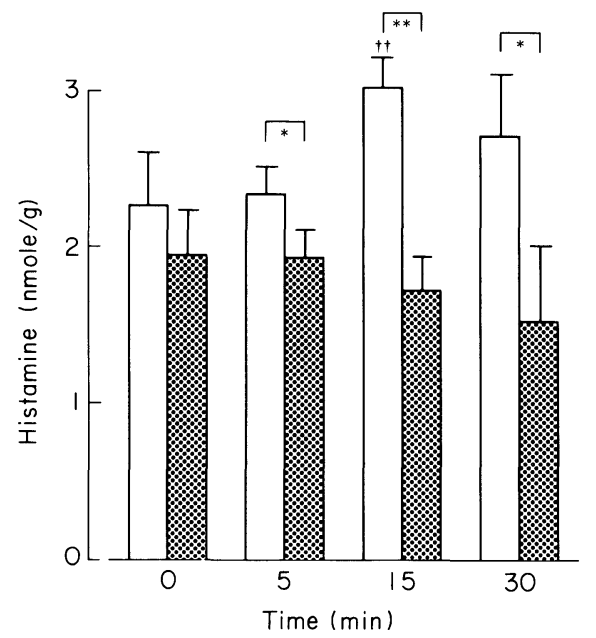

Fig. 3. Circadian variations in the GRF-induced histamine response in the anterior and posterior hypothalamic regions. The animals received an i.c.v. injection of $\mathrm{GRF}_{1-44}$ at $10: 00 \mathrm{a} . \mathrm{m}$. ( $\square$ ) or 8:00 p.m. (W. in Materials and Methods, and the GRF-induced histamine responses in the anterior and posterior hypothalamic regions were measured 5, 15, and $30 \mathrm{~min}$ later.

$n=5-7$ rats/group. $\dagger \dagger p<0.01$ vs. control $(0) .{ }^{*} p<0.05$ and ${ }^{* *} p<0.01$ vs. corresponding value at 8 p.m. 


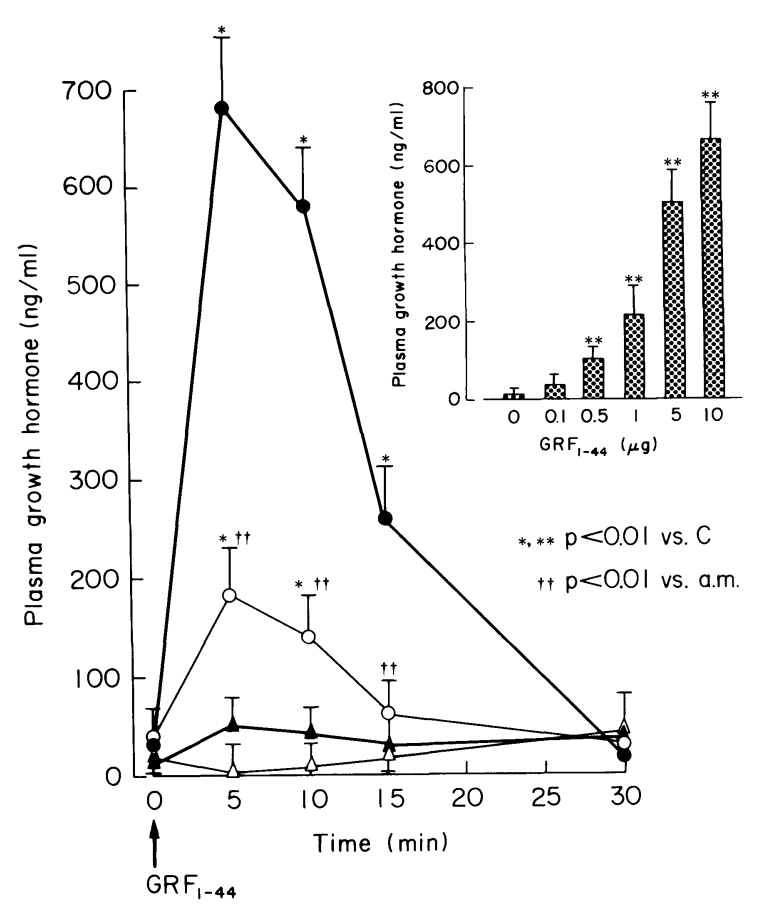

Fig. 4. Circadian variations in the GRF-induced GH response in plasma.

The animals were treated with $\operatorname{GRF}_{1-44}(10 \mu$ g, i.p. (•) or i.c.v. $(\mathbf{\wedge}))$ at $10: 00$ a.m. or $8: 00$ p.m. (i.p. $=(\bigcirc)$; i.c.v. $=\triangle$ ) and plasma $\mathrm{GH}$ level was measured by RIA 5, 10, 15 and 30 min later ( $n=5-6$ rats/group). For examination of the dose-dependence of GH secretion (stippled bars) animals ( $n=6$ rats/group) were killed $7 \mathrm{~min}$ after GRF i.p. injection.

increases in the concentration of HA in the AHR after 15 min (Fig. 3), but when given in the evening no response was observed (Fig. 3). The circadian variation in the GRF-induced HA response was most significant after $15 \mathrm{~min}$ (Fig. 3), but in the PHR, clear circadian changes were observed after 5, 15 and 30 min (Fig. 3). In this region, the basal and GRF-stimulated HA levels were both lower in the evening than in the morning (Fig. 3).

Circadian variations in the GRF-induced $\mathrm{GH}$ response were also highly significant. In the morning i.p. GRF elicited a high peak of GH at 5-15 min (Fig. 4) while in the evening the GRF-induced GH response was less significant. The i.c.v. injection of GRF did not elicit a response in the morning and tended to decrease the plasma GH levels in the evening (Fig. 4). The response of $\mathrm{GH}$ to GRF (i.p.) was dose-dependent in the morning $\left(\mathrm{ED}_{50}=4.5 \times 10^{-7} \mathrm{M} ; \mathrm{E}_{\max }=2.0 \times\right.$ $10^{-9} \mathrm{M}$ ) (Fig. 4) but not in the evening.

\section{Discussion}

According to our data, $\mathrm{GRF}_{1-44}$ can induce changes in the concentration of 
HA in the CNS (Figs. 1, 2, 3) when administered i.c.v. The GRF-induced HA response was found to be time- and dose-dependent in five different regions of the HhS (Figs. 1, 2) but the concentration of GRF necessary to increase the levels of HA $\left(2-5 \times 10^{-5} \mathrm{M}\right)$ was higher than that necessary to induce the release of GH in vivo $\left(\mathrm{ED}_{50}=1.9 \times 10^{-7} \mathrm{M}\right)$ or in vitro $\left(\mathrm{ED}_{50}=1.2 \times 10^{-11} \mathrm{M}\right)$ in rats (Wehrenberg and Ling 1983 ; Guillemin et al. 1984 ; Ling et al. 1984) and in monkeys (Almeida et al. 1984). The HA response to GRF in the ME coincided with the GRFinduced GH response in the plasma. In the hypothalamus, the HA response was 5-10 min later than the release of $\mathrm{GH}$ from the Ah.

In in vitro studies (Guillemin et al. 1984a, b ; Ling et al. 1984) $\mathrm{GRF}_{1-44}$ was the most potent of the C-terminal deleted analogs tested in a normal pituitary cell monolayer culture system $\left(\mathrm{ED}_{50}=12 \mathrm{pM} ; \mathrm{E}_{\max }=100 \mathrm{pM}\right)$ (Guillemin et al. 1984a, b). In our studies, $\mathrm{GRF}_{1-29}$ and $\mathrm{GRF}_{1-44}$ were aproximately equipotent $\left(\mathrm{GRF}_{1-29} \mathrm{E}_{\max }=1.5 \times 10^{-4} \mathrm{M} ; \mathrm{GRF}_{1-44} \mathrm{E}_{\max }=2 \times 10^{-4} \mathrm{M}\right)$ in eliciting changes of HA in the brain (Cacabelos et al. 1986a, b, c ; Tanaka et al. 1986). Although the GRF receptors mediating GH secretion at the pituitary level and those mediating central actions may differ, a similar amino-terminal portion of the GRF molecule is most probably involved in the binding to the receptors, and deletion of the C-terminal residues 30-44 of GRF does not seem to affect its biological potency in releasing brain $\mathrm{HA}$ in the rat.

The i.p. injection of $\mathrm{GRF}_{1-44}$ resulted in decreases in the HA levels in the hypothalamus (Table 1). The HA responses in the ME and Nh were higher after i.p. injection of GRF than after its i.c.v. injection. This suggests that although GRF partially crosses the blood-brain barrier (bbb) (Banks and Kastin 1985), its main direct action after its i.p. administration is on areas of the HhS located outside the bbb (i.e., the ME and hypophysis) (Meisenberg and Simmons 1983). In these regions, it may activate histaminergic and somatotropinergic short feedback loops (Cacabelos et al. 1986b) that influence the release of $\mathrm{HA}$ at the hypothalamic level. The intrinsic mechanism of interaction of GRF with neuronal HA is still unknown. However, what seems clear is that when administered by different routes (i.e., i.p., i.c.v.) GRF has opposite effects on the HA response in the hypothalamus but similar effects on the response of $\mathrm{HA}$ in the $\mathrm{ME}$ and hypophysis. This fact provides indirect evidence that GRF may have different physiological roles in the central and peripheral compartments with regard to its interaction with the histaminergic system.

The effect of HA on GH release is still controversial. In a recent review, Tuomisto and Mannisto (1985) suggested that HA is not an important neurotransmitter in the regulation of GH secretion in humans (Carlson and Chang 1980). However, when pituitary glands are incubated with hypothalamic fragments, HA at concentrations of $10^{-8}-10^{-7} \mathrm{M}$ stimulates the release of $\mathrm{GH}$ (Hall et al. 1984) and this effect can be blocked by the H-1 antagonist diphenhydramine (Hall et al. 1984). We have reported that i.p. HA at a dose of $6 \mu \mathrm{mole} / \mathrm{kg}$ induces a 
significant increase in the basal level of GH in rats, and that this effect is abolished by famotidine, a specific H-2 antagonist (Cacabelos et al. 1986c; Tanaka et al. 1986). Our data suggest that at least at the pituitary level, HA can influence the release of $\mathrm{GH}$ in vivo through $\mathrm{H}-2$ receptors (Cacabelos et al. 1986c ; Tanaka et al. 1986). This is partially in agreement with the fact that although GRF stimulates the release of $\mathrm{HA}$ in the $\mathrm{HhS}$, the repeated administration of the neuropeptide does not alter the total amount of $\mathrm{H}-1$ receptors (Table 3). Desensitization to GRF associated with down-regulation of GRF-binding sites (Bilezikjian et al. 1986) cannot be ruled out, because chronic exposure of the pituitary to maximum concentrations of GRF causes partial loss of responsiveness in vivo (Gelato et al. 1985 ; Wehrenberg et al. 1986) and in vitro (Bilezikjian and Vale 1984). However, in our studies neither single nor repeated doses of GRF affected $\left[{ }^{3} \mathrm{H}\right]$ mepyramine binding in different regions of the HhS where i.p. administration of GRF induced HA responses.

Netti and coworkers $(1982,1984)$ have reported that HA can inhibit pulsatile GH secretion through a central mechanism, although i.c.v. administration of HA, $\mathrm{H}-1$ and $\mathrm{H}-2$ agonists or antagonists had no effect on the basal plasma GH level (Netti et al. 1981 ; Knigge et al. 1984). These workers suggested that HA has an inhibitory influence on GRF (Netti et al. 1984), a possibility that is not consistent with the report by Tanaka et al. (1986) that HA potentiates the GRF-induced GH response at $10 \mathrm{~min}$. In connection with these discrepant findings, it should be mentioned that HA probably plays some role in generating an ultradian rhythm of $\mathrm{GH}$ secretion through an interaction with GRF and somatostatin. In the rat, GH secretion shows an endogenous ultradian rhythm with secretory bursts occurring at 3 -h intervals (Tannenbaum and Ling 1984). In contrast, hypothalamic HA has a circadian rhythm with a minimum in the evening and maximum in the morning in rats (Wada and Cacabelos 1984 ; Wada et al. 1985 ; Yamatodani et al. 1985a). In our studies, both HA and GH responded to GRF stimulation in the morning, when the basal HA levels in the hypothalamus are relatively high, but did not respond to GRF in the evening, when the levels of HA in the posterior hypothalamus are lowest (Wada et al. 1985; Yamatodani et al. 1985a). Studies are required on whether $\mathrm{HA}$ is responsible for the failure of $\mathrm{GH}$ to respond to GRF stimulation in the evening. The influence of somatostatin in these circadian variations of $\mathrm{GH}$ and $\mathrm{HA}$ in response to GRF must be taken into account, because GRF itself can stimulate the release of somatostatin in the ME and this stimulation of somatostatin release may be why GRF exerts a negative ultrashort-loop feedback to inhibit GH release (Tannenbaum 1984 ; Tannenbaum and Ling 1984 ; Aguila and McCann 1985). But actually we do not know whether this effect influences the HA circadian rhythm.

Several conclusions can be made from the present results :

(1) $\mathrm{GRF}_{1-44}$ can induce dose- and time-dependent changes in the concentration of HA in the HhS. Since changes in the concentration of HA in the ME and 
hypophysis coincide with the GH response to GRF and since the HA response in the hypothalamus occurs 5-10 min later, the central stimulation of HA may have an inhibitory effect on the secretion of GH after the secretory burst induced by GRF.

(2) The GRF-induced HA response in the hypothalamus differs depending on whether GRF is administered i.c.v. or i.p., but the HA responses in the ME and hypophysis are the same irrespective of the route of GRF administration. These observations indicate that GRF plays different interactive roles with $\mathrm{HA}$ in the central and peripheral compartments.

(3) GRF does not affect $\left[{ }^{3} \mathrm{H}\right]$-mepyramine binding in the HhS. Thus the effects of HA in response to GRF may not be mainly mediated through $\mathrm{H}-1$ receptors.

(4) Both GH and HA have a blunted response to GRF in the evening. This finding suggests some functional interactions between HA and GRF-somatostatin to elicit an ultradian rhythm of GH secretion which in rats is more apparent in the morning than in the evening.

\section{Acknowledgments}

This study was supported in part by grants-in-aid from the Ministry of Education, Science and Culture and the Ministry of Health and Welfare of Japan. We thank Dr. Kazuko Murakoshi and Dr. Junya Tanaka for technical assistance, and Sumitomo Pharmaceutical Co. for a generous supply of $\mathrm{GRF}_{1-44}$.

\section{References}

1) Aguila, M.C. \& McCann, S.M. (1985) Stimulation of somatostatin release in vitro by synthetic human growth hormone-releasing factor by a nondopaminergic mechanism. Endocrinology, 117, 762-765.

2) Almeida, O.F.X., Schulte, H.M., Rittmaster, R.S., Chrousos, G.P., Loriaux, D.L. \& Merriam, G.R. (1984) Potency and specificity of a growth hormone-releasing factor in a primate in vivo and in vitro. J. clin. Endocr., 58, 309-312.

3) Banks, W.A. \& Kastin, A.J. (1985) Peptides and the blood-brain barrier: Lipophilicity as a predictor of permeability. Brain Res. Bull., 15, 287-292.

4) Bilezikjian, L.M., Seifert, H. \& Vale, W. (1986) Desensitization to growth hormonereleasing factor (GRF) is associated with down-regulation of GRF-binding sites. Endocrinology, 118, 2045-2052.

5) Bilezikjian, L.M. \& Vale, W.W. (1984) Chronic exposure of culture rat anterior pituitary cells to GRF causes partial loss of responsiveness to GRF. Endocrinology, 115, 2032-2034.

6) Bloch, B., Brazeau, P., Ling, N., Bohlen, P., Esch, F., Wehrenberg, W.B., Benoit, R., Bloom, F. \& Guillemin, R. (1983) Immunohistochemical detection of growth hormone-releasing factor in brain. Nature (Lond.), 301, 607-608.

7) Cacabelos, R. (1984) Role of histamine in the neuroendocrine system. JANO Med. Hum., 638, 46-61.

8) Cacabelos, R. (1985a) Histaminology. Med. clin. (Barcelona), 84, 524-527.

9) Cacabelos, R. (1985b) Histaminergic Modulation of the Neuroendocrine System. Santiago University Press, Santiago de Compostela, Spain.

10) Cacabelos, R., Yamatodani, A., Wada, H., Hariguchi, S. \& Nishimura, T. (1983) 
Histamine within the hypothalamo-hypophyseal system after bilateral adrenalectomy. Bull. Jap. Neurochem. Soc., 22, 342-344.

11) Cacabelos, R., Takagi, T., Otsuki, Y., Sugita, N., Hariguchi, S., Nishimura, T. \& Tanizawa, O. (1985a) Chronobiological analysis of the effects produced by adrenalectomy on the oxytocinergic and vasopressinergic systems. Endocrinologia, 32, 126-135.

12) Cacabelos, R., Yamatodani, A., Fukui, H., Watanabe, T., Hariguchi, S., Nishimura, T. $\&$ Wada, H. (1985b) Nature of histaminergic neuromodulation of the corticotropinergic system. Biogenic Amines, 3, 9-19.

13) Cacabelos, R., Fukui, H., Yamatodani, A., Wada, H., Niigawa, H., Rodriguez-Arnao, M.D., Gomez-Pan, A. \& Nishimura, T. (1986a) Influence of GRF on histamine, H-1 receptors and cAMP in the CNS. Abstr. Int. Symp. GRF, Growth Hormone \& Somatomedin, Tokyo, p. 26.

14) Cacabelos, R., Niigawa, H. \& Hariguchi, S. (1986b) Hypothalamo-hypophyseal system and brain function. J. clin. Sci., 22, 1108-1120. (Japanese)

15) Cacabelos, R., Yamatodani, A., Miyake, A., Niigawa, H., Tada, K., Hariguchi, S., Nishimura, T. \& Wada, H. (1986c) Functional interactions of histamine with GRF and GH. Acromegaly Centennial Symp., San Francisco, p. 29.

16) Cacabelos, R., Yamatodani, A., Niigawa, H., Hariguchi, S., Nishimura, T. \& Wada, H. (1987) Histaminergic neuromodulation of the release of vasopressin. Neuroendocrinology, 45, 368-375.

17) Carlson, H.E. \& Chang, R.J. (1980) Studies on the role of histamine in human pituitary function. Clin. Endocr., 12, 461-466.

18) Chang, R.S.L., Tran, V.T. \& Snyder, S.H. (1978) Histamine H-1 receptors in brain labeled with ${ }^{3} \mathrm{H}$-mepyramine. Europ. J. Pharmacol., 48, 463-464.

19) Donoso, A.O. \& Alvarez, E.O. (1984) Brain histamine as neuroendocrine transmitter. Trends. pharma. Sci., 5, 98-100.

20) Gelato, M.C., Rittmaster, R.S., Pescovitz, O.H., Nicoletti, M.C., Nixon, W.E., D'Agata, R., Loriaux, D.L. \& Merriam, G.R. (1985) Growth hormone responses to continuous infusions of growth hormone-releasing hormone. J. clin. Endocr., 61, 223-228.

21) Green, J.P., Johnson, C.L. \& Weinstein, H. (1978) Histamine as a neurotransmitter. In: Psychoneuropharmacology: A Generation of Progress, edited by M.A. Lipton, A. DiMascio \& D.F. Killam, Raven Press, New York, pp. 319-332.

22) Guillemin, R., Brazeau, P., Bohlen, P., Esch, F., Ling, N., Wehrenberg, W.B., Bloch, B., Mougin, C., Zeytin, F. \& Baird, A. (1984a) Somatocrinin, the growth hormone releasing factor. Progr. Horm. Res., 40, 233-299.

23) Guillemin, R., Zeytin, F., Ling, N., Bohlen, P., Esch, F., Brazeau, P., Bloch, B. \& Wehrenberg, W.B. (1984b) Growth hormone-releasing factor : Chemistry and physiology. Proc. Soc. exp. Biol. Med., 175, 407-413.

24) Hall, T.R., Harvey, S. \& Chadwick, A. (1984) Prolactin and growth hormone secretion in chickens: Stimulation by histamine and inhibition by gamma-aminobutyric acid. Acta endocr. (Buc.), 107, 36-41.

25) Knigge, U., Thuesen, B., Wollesen, F., Dejgaard, A. \& Christiansen, P.M. (1984) Histamine-induced paradoxical growth hormone response to thyrotropin-releasing hormone in normal men. J. clin. Endocr., 58, 692-697.

26) Ling, N., Baird, A., Wehrenberg, W.B., Ueno, N., Munegumi, T. \& Brazeau, P. (1984) Synthesis and in vitro bioactivity of C-terminal deleted analogs of human growth hormone-releasing factor. Biochem. biophys. Res. Commun., 123, 854-861.

27) Meisenberg, G. \& Simmons, W.H. (1983) Peptides and the blood-brain barrier. Life Sci., 32, 2611-2623.

28) Meister, B., Hökfelt, T., Vale, W.W. \& Goldstein, M. (1985) Growth hormone releasing factor $(\mathrm{GRF})$ and dopamine coexist in hypothalamic arcuate nucleus. Acta physiol. scand., 124, 133-136. 
29) Merchenthaler, I., Vigh, S., Schally, A.V. \& Petrusz, P. (1984) Immunocytochemical localization of growth hormone releasing factor in the rat hypothalamus. Endocrinology, 114, 1082-1085.

30) Netti, C., Guidobono, F., Olgiati, V.R., Sibilia, V., Pagani, F. \& Pecile, A. (1982) Influence of brain histaminergic system on episodic growth hormone secretion in the rat. Neuroendocrinology, 35, 43-47.

31) Netti, C., Guidobono, F., Olgiati, V.R., Sibilia, A. \& Pecile, A. (1981) Histamine agonist and antagonist drugs: Interference with CNS control of $\mathrm{GH}$ release in rats. Horm. Res., 14, 180-191.

32) Netti, C., Guidobono, F., Sibilia, V., Olgiati, V.R., Pagani, F. \& Pecile, A. (1984) Failure of somatostatin antiserum to reverse histamine-induced inhibition of pulsatile growth hormone secretion. Horm. Res., 19, 12-17.

33) Panula, P., Yang, H.T.T. \& Costa, E. (1984) Histamine-containing neurons in the rat hypothalamus. Proc. nat. Acad. Sci. USA, 81, 2572-2576.

34) Prell, G.D. \& Green, J.P. (1986) Histamine as a neuroregulator. Ann. Rev. Neurosci., 9, 209-254.

35) Roberts, F. \& Calcutt, C.R. (1983) Histamine and the hypothalamus. Neuroscience, 9, 721-739.

36) Schwartz, J.C., Pollard, H. \& Quach, T.T. (1980) Histamine as a neurotransmitter in mammalian brain: Neurochemical evidence. $J$. Neurochem., 35, 26-33.

37) Senba, E., Daddona, P.E., Watanabe, T., Wu, J.Y. \& Nagy, J.I. (1985) Coexistence of adenosine deaminase, histidine decarboxylase, and glutamate decarboxylase in hypothalamic neurones of the rat. J. Neurosci., 5, 3393-3402.

38) Steinbusch, H.W.M. \& Mulder, A.H. (1984) Immunohistochemical localization of histamine in neurons and mast cells in the rat brain. In: Handbook of chemical neuroanatomy. Vol. 3. Classical Transmitters and Transmitter Receptors in the CNS. Part II, edited by A. Björklund, T. Hökfelt \& M.J. Kuhar. Elsevier, Amsterdam, pp. $126-140$.

39) Takeda, N., Inagaki, S., Taguchi, Y., Tohyama, M., Watanabe, T. \& Wada, H. (1984) Origins of histamine-containing fibers in the cerebral cortex of rats studied by immunohistochemistry with histidine decarboxylase as a marker and transsection. Brain Res., 323, 55-63.

40) Tanaka, J., Yamatodani, A., Niigawa, H., Miyake, A., Murakoshi, K., Tada, K., Hariguchi, S., Wada, H., Nishimura, T. \& Cacabelos, R. (1986) GRF-induced histamine response in the central nervous system and the effects of histamine and $\mathrm{HA}$-antagonists on the GH response to GRF. Abstr. Int. Symp GRF, Growth Hormone \& Somatomedin, Tokyo, p. 26.

41) Tannenbaum, G.S. (1984) Growth hormone-releasing factor: Direct effects on growth hormone, glucose, and behavior via the brain. Science, 226, 464-466.

42) Tannenbaum, G.S. \& Ling, N. (1984) The interrelationship of growth hormone $(\mathrm{GH})$-releasing factor and somatostatin in generation of the ultradian rhythm of GH secretion. Endocrinology, 115, 1952-1957.

43) Tran, V.T., Chang, R.S.L. \& Snyder, S.H. (1978) Histamine H-1 receptors identified in mammalian brain with ${ }^{3} \mathrm{H}$-mepyramine. Proc. nat. Acad. Sci. USA, 75, 6290-9294.

44) Tuomisto, J. \& Mannisto, P. (1985) Neurotrasmitter regulation of anterior pituitary hormones. Pharmacol. Rev., 37, 249-332.

45) Wada, H. \& Cacabelos, R. (1984) Introduction to brain histamine. JANO Med. Hum., 636, 43-54.

46) Wada, H., Watanabe, T., Yamatodani, A., Maeyama, K., Itoi, N., Cacabelos, R., Seo, M., Kiyono, S., Nagai, K. \& Nakagawa, H. (1985) Physiological functions of histamine in the brain. Advanc Biosci., 51, 225-235.

47) Wahlestedt, C., Skagerberg, G., Håkanson, R., Sundler, F., Wada, W. \& Watanabe, T. (1985) Spinal projections of hypothalamic histidine decarboxylase-immunoreactive 
neurons. Agents Actions, 16, 231-233.

48) Watanabe, T., Taguchi, Y., Shiosaka S., Tanaka, J., Kubota, H., Terano, Y., Tohyama, M. \& Wada, H. (1984) Distribution of the histaminergic neuron system in the central nervous system of rats; a fluorescent immunohistochemical analysis with histidine decarboxylase as a marker. Brain Res., 295, 13-25.

49) Wehrenberg, W.B. \& Ling, N. (1983) In vivo biological potency of rat and human growth hormone-releasing factor and fragments of human growth hormone-releasing factor. Biochem. biophys. Res. Commun., 115, 525-530.

50) Wehrenberg, W.B., Seifert, H., Bilezikjian, L.M. \& Vale, W. (1986) Down-regulation of growth hormone releasing factor receptors following continuous infusion of growth hormone releasing factor in vivo. Neuroendocrinology, 43, 266-268.

51) Weiner, R.I. \& Ganong, W.F. (1978) Role of brain monoamines and histamine in regulation of anterior pituitary secretion. Physiol. Rev., 58, 905-976.

52) Yamatodani, A., Cacabelos, R., Watanabe, T. \& Wada, H. (1985a) Effect of alphafluoromethylhistidine (FMH) on circadian rhythm and neurosecretory system. Jap. J. Pharmacol., 39, 87 p.

53) Yamatodani, A., Fukuda, H., Iwaeda, T., Watanabe, T. \& Wada, H. (1985b) HPLC determination of plasma and brain histamine without previous purification of biological samples: Cation exchange chromatography coupled with postcolumn derivatization fluorometry. J. Chromat., 344, 115-123.

54) Yamatodani, A., Watanabe, T. \& Wada, H. (1983) Methods for determination of histamine in biological materials. In: Methods in Biogenic Amine Research, edited by S. Parvez, T. Nagatsu, I. Nagatsu \& H. Parvez, Elsevier, Amsterdam, pp. 663-687. 